\title{
Effects of initial periodontal therapy on the prevalence of Epstein-Barr virus DNA and Porphyromonas gingivalis in Japanese chronic periodontitis patients
}

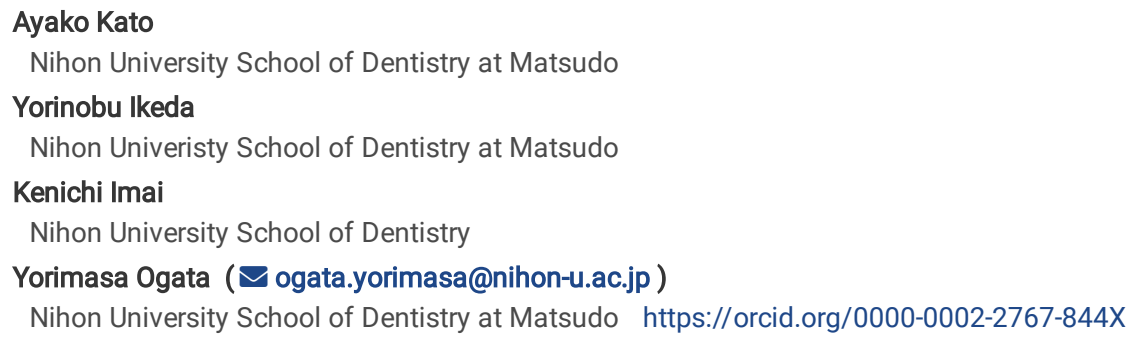

\section{Research article}

Keywords: Epstein-Barr virus, initial periodontal therapy, Porphyromonas gingivalis, periodontitis, prevalence

Posted Date: October 23rd, 2019

DOI: https://doi.org/10.21203/rs.2.16315/v1

License: () (1) This work is licensed under a Creative Commons Attribution 4.0 International License. Read Full License 


\section{Abstract}

Background Initial periodontal therapy (IPT) is cornerstone of periodontal therapy and the first step to control of periodontal risk factors. Scaling and root planing are used to treat root surface irregularities and remove virulent factors caused by periodontal pathogens. This procedure also incorporated into periodontal surgery. To elucidate the effects of IPT on prevalence of Epstein-Barr virus (EBV) DNA and Porphyromonas gingivalis, we used subgingival plaque samples from chronic periodontitis (CP) patients.

Methods Seventeen CP patients were recruited and determined measured periodontal status clinical parameters such as by probing depth (PD), clinical attachment level (CAL), bleeding on probing (BOP) and an X-ray examination, and subgingival plaque samples were collected from two periodontal sites with PD of $<3 \mathrm{~mm}$ (healthy sites: HS) or $>5 \mathrm{~mm}$ (periodontitis sites: PS) at first visit and after IPT. Plaque samples were subjected to a real-time PCR to detect EBV DNA and P. gingivalis.

Results EBV DNA and P. gingivalis were detected 9 (52.9\%) and 14 (82.3\%) sites within the subgingival samples from HS, and 13 (76.5\%) and 14 (82.3\%) sites within the PS at first visit. After IPT, number of detections of EBV DNA and P. gingivalis were decreased to 5 (29.4\%) and 13 (76.5\%) sites within the subgingival samples from HS, and 9 (52.9\%) and 10 (58.8\%) sites within the PS. Significant improvements in PD and BOP were observed after IPT in PS. Coexistence of EBV DNA and P. gingivalis in the subgingival samples from PS at first visit (12 sites; 70.6\%) were significantly decreased after IPT (6 sites; $35.3 \%)$.

Conclusion These results suggest that the IPT was effective in improvement of clinical parameters such as PD and BOP and reducing the coexistence of EBV and P. gingivalis in the subgingival plaque from PS. However, IPT could not eradicate the EBV and P. gingivalis . Further research would be necessary for improving the periodontal treatment strategy.

\section{Background}

Patient education, training in oral hygiene, control of risk factors, removal of supra and subgingival bacterial plaque, scaling and root planing (SRP) are contents of implementation of initial periodontal therapy (IPT) [1, 2]. EBV is one of the most prevalent viruses in the world. It is estimated that over $90 \%$ of adults are EBV seropositive [3, 4]. Primary infections of infants with EBV are usually asymptomatic, but the infection of adolescence and young adult with EBV causes infectious mononucleosis, a self-limiting, lymphoproliferative disease. Spread within families is thought to be a common route of EBV transmission by salivary contact. The virus infects first within oropharyngeal epithelium, and later primarily within B lymphocytes are invaded via CD21 receptors, where it establishes a lifelong latent infection [5-9]. EBV has been linked to the development of several malignant tumors, including Burkitt's lymphoma, Hodgkin's disease certain forms of T-cell lymphoma, lymphoproliferative disease in immunosuppressed individuals, nasopharyngeal carcinoma and a proportion of gastric cancers [10-12]. ZEBRA is an early lytic protein of EBV encoded BZLF1 gene. In the latent state, hypoacetylation of histone in the BZLF1 promoter by histone deacetylases is involved in maintaining EBV latency. The reactivation of EBV from latent infection occurs frequently and multiplies with the epithelium cells of the pharyngeal and is exhausted in saliva [7, 13-15].

Association between EBV infection and periodontal disease has been reported [16, 17]. Therefore, we have examined the coexistence of EBV and Porphyromonas gingivalis which is a representative periodontal pathogen in the subgingival plaque from two periodontal sites with probing depth (PD) of $<3$ $\mathrm{mm}$ or $>5 \mathrm{~mm}$. EBV DNA and $P$. gingivalis were detected in higher copy numbers in deep periodontal pockets and showed a higher incidence of the coexistence as compared to shallow periodontal pockets $[18,19]$. We showed that EBV may serve as a pathogenic factor leading to CP among Japanese patients.

Periodontopathic anaerobic bacteria such as $P$. gingivalis could increase the virulence of EBV via reactivation of EBV through butyric acid [18, 19]. The findings of the meta-analysis suggest that EBV and human cytomegalovirus are significantly associated with CP [20]. EBV and $P$. gingivalis coinfection may promote the development of $\mathrm{CP}$ in pregnant women [21]. Therefore, it might be potential interactions between EBV and $P$. gingivalis in the etiopathogenesis of $\mathrm{CP}$

The purpose of this study was to examine the effects of IPT on the prevalence of Epstein-Barr virus (EBV) DNA and $P$. gingivalis in the subgingival plaque.

\section{Methods}

\section{Clinical examination and characteristics of participants}

Periodontal examination comprising determination of PD, clinical attachment level (CAL), bleeding on probing (BOP) and an X-ray (intraoral radiograph) examination. At each point in time, periodontal examinations were performed by a trained periodontist (YO) using PCP11 probe (Hu-Friedy, Chicago, IL, USA) according to the method has been published previously [23]. CP patients were defined as the presence of at least two sites with PD $>5 \mathrm{~mm}$ and CAL of more than $5 \mathrm{~mm}$. Seventeen CP patients (mean age, $44.8 \pm 14.9$ years) were included in this study. All subjects were systemically healthy and had no history of periodontal treatment or any type of antibiotic therapy for at least 3 months prior to the present study. The Institutional Review Board at the Nihon University School of Dentistry at Matsudo approved the study (EC17-16-15-005-2). Written informed consent was obtained from each study subject after all experiments were fully explained. They received IPT, such as oral hygiene instructions, SRP and mechanical tooth cleaning (within 12 months) at Nihon University Hospital School of Dentistry at Matsudo, Japan.

\section{Sampling}

Seventeen subgingival plaque samples were collected from one periodontally healthy site (HS) of PD ( $<3 \mathrm{~mm})$, and one periodontitis site (PS) of PD ( $>5 \mathrm{~mm}$ ) among $17 \mathrm{CP}$ patients at first visit and after initial periodontal therapy. Before sampling, supragingival plaque was removed with Gracey curette. Sterile paper points were inserted to the sample site (three times), retained for $30 \mathrm{sec}$, pooled in Eppendorf tubes, and then stored at $-80{ }^{\circ} \mathrm{C}$ [18]. 


\section{DNA extraction and real-time PCR}

DNA samples from the subgingival plaque were prepared using High Pure Viral Nucleic Acid Kit (Roche Applied Science, Mannheim, Germany). Quantitative real-time polymerase chain reaction (PCR) was used to measure the copy numbers of EBV DNA and $P$. gingivalis in the samples, using the specific primer sets described previously. $[19,24]$. The dynamic ranges of the real-time PCR assays were determined through serial dilution of DNA extracts either as AKATA cells or $P$. gingivalis TDC60 of the standards in the range of $10^{9} \sim 10^{1}$ copies $/ \mathrm{ml}[25,26]$.

\section{Statistical analysis}

The chi squared test for independence, confirmed by Fisher's exact probability test, was used to determine whether individual pathogens and BOP were changed by IPT. Significant differences between baseline values of PD and values after IPT were analyzed using one-way ANOVA.

\section{Results}

The age, sex, PD, CAL and BOP of the patients are summarized in Table 1. Seven males and 10 females were included in this study. The mean PD of the HS and PS at first visit were $2.94 \pm 0.24 \mathrm{~mm}$ and $7.35 \pm 1.54 \mathrm{~mm}$, and then they were changed to $2.82 \pm 0.39 \mathrm{~mm}$ (HS) and $5.76 \pm 1.68 \mathrm{~mm}$ (PS) after IPT. The mean CAL of the HS and PS at first visit were $3.65 \pm 1.37 \mathrm{~mm}$ and $8.76 \pm 1.92 \mathrm{~mm}$, and then they were changed to $3.82 \pm 1.51 \mathrm{~mm}$ (HS) and $7.47 \pm 1.74 \mathrm{~mm}$ (PS) after IPT. BOP was detected in 2 (11.8\%) HS and 17 (100\%) PS at first visit, and then BOP could not detect in HS and detected in 11 (65\%) PS after IPT. PD and BOP of the PS at first visit were significant improved after IPT. Table 2 and 3 show gender, age, clinical data and counts of EBV DNA and $P$. gingivalis (copies/ml) of each subject in the HS and PS at first visit and after IPT. EBV DNA and $P$. gingivalis were detected 9 sites ( $52.9 \%$, range from $2.52 \times 10^{2}$ to $1.09 \times 10^{4}$ copies $/ \mathrm{ml}$ ) and 14 sites $\left(82.3 \%\right.$, range from $5.29 \times 10^{1}$ to $\left.4.71 \times 10^{8} \mathrm{copies} / \mathrm{ml}\right)$ in the subgingival samples from $\mathrm{HS}$ at first visit and changed to 5 sites (29.4\%, range from $6.12 \times 10^{2}$ to $8.41 \times 10^{3}$ copies $/ \mathrm{ml}$ ) and 13 sites $\left(76.5 \%\right.$, range from 4.34 to $7.61 \times 10^{7}$ copies/ml) from HS after IPT (Table 2$)$. EBV DNA and P. gingivalis were detected 13 sites $\left(76.5 \%\right.$, range from $3.78 \times 10^{1}$ to $2.55 \times 10^{4}$ copies $\left./ \mathrm{ml}\right)$ and 14 sites $\left(82.3 \%\right.$, range from $2.28 \times 10^{3}$ to $6.21 \times 10^{9}$ copies $\left./ \mathrm{ml}\right)$ in the subgingival samples from PS at first visit and changed to 9 sites $\left(52.9 \%\right.$, range from $6.50 \times 10^{2}$ to $\left.8.59 \times 10^{3} \mathrm{copies} / \mathrm{ml}\right)$ and 10 sites $(58.8 \%$, range from $9.97 \times 10^{1}$ to $2.70 \times 10^{9}$ copies $/ \mathrm{ml}$ ) from PS after IPT.

The prevalence of EBV DNA and $P$. gingivalis in the subgingival samples from HS or PS are listed in Table 4 and 5. Occurrence of EBV DNA and $P$. gingivalis in the HS or PS were decreased after IPT, but not statistically significant. Coexistence of EBV DNA and $P$. gingivalis in the PS at first visit (12; 70.6\%) were significantly decreased after IPT $(6 ; 35.3 \%)$ (Table 5). However, coexistence of EBV DNA and $P$. gingivalis in the HS did not decreased significantly after IPT (Table 4).

\section{Discussion}

In this study, we demonstrated that higher levels of EBV DNA, $P$. gingivalis and coexistence of EBV DNA and $P$. gingivalis were detected in the HS and PS of Japanese CP patients and they were decreased by IPT. Especially, PD, BOP and coexistence of EBV DNA and $P$. gingivalis in the PS at first visit were significant decreased after IPT. The results suggest that IPT is effective in improvement of PD and BOP and reducing the coexistence of EBV and $P$. gingivalis in the subgingival plaque.

Periodontopathic bacteria is major risk factor for periodontal disease, however does not satisfied only by bacterial activity to explain several clinical characteristics of periodontitis, such as rapid bone resorption with minimal amount of plaque, site specific development, and presence of quiescence and active phase. Therefore, EBV could be involved in the etiology of several types of periodontitis [18, 27-29]. In this study, we examined whether higher prevalence of EBV DNA and $P$. gingivalis are associated with PS in Japanese CP patients and IPT could decrease the number of EBV and $P$. gingivalis in the subgingival plaque, because several studies suggest that EBV and $P$. gingivalis act synergistically to potentiate periodontal disease progression and tissue destruction $[18,19,21,29,30]$. In this study, EBV DNA and $P$. gingivalis coexist in the PS of CP patients at high frequency (70.6\%). This value correlated with previous studies that showed higher levels (68\%) of EBV DNA and P. gingivalis coexist in the deep PD (>5 mm) in the CP patients [19]. EBV were associated with major periodontopathic bacteria and with the severity of periodontal disease [31,32]. These reports suggested that high copy numbers of EBV DNA and $P$. gingivalis may correlate with periodontal disease state. In our previous report, detection rate and counts in PCR-positive deep PD $>5 \mathrm{~mm}$ (PS) or sallow PD of $<3 \mathrm{~mm}$ (HS) sites for EBV DNA (detected in $6080 \%$ PS and 40\% HC sites) were $3.74 \times 10^{3} \sim 3.70 \times 10^{7}$ and $4.37 \times 10^{4} \sim 9.13 \times 10^{6} \mathrm{copies} / \mathrm{ml}$, and for $P$. gingivalis (detected in $80 \%$ PS and $36 \% \mathrm{HC}$ sites) were $2.45 \times 10^{7} \sim 1.15 \times 10^{9}$ and $4.16 \times 10^{6} \sim 2.13 \times 10^{9}$ copies/ml [19]. The results showed that detection rate of EBV DNA and $P$. gingivalis in the PS were similar in this study, whereas detection rate in the HS were higher in this study (Table 2-5).

We have previously reported that immunostaining using B cell marker CD19 showed large number of B cells infiltrated into the inflamed gingival connective tissues [18]. And the results of in-situ hybridization using serial section by EBV-encoded small RNA (EBRE) showed a large number of B cells in the same location were EBER-positive [18].

Latent EBV could be induced into the lytic replication cycle by treatment with several inducers, such as anti-immunoglobulin, butyric acid, calcium ionophore, phorbol 12-myristate 13-acetate and transforming growth factor- $\beta[7,8,33]$. The EBV BZLF1 gene product ZEBRA is a regulator of the transition from latent form to the lytic replication cycle. Histone deacetylase (HDAC) induces hypoacetylation of histone in the BZLF1 promoter, and it is involved in the maintaining of EBV latency. Culture supernatant of $P$. gingivalis contains butyric acid which is an inhibitor of HDAC, increased histone acetylation and transcriptional activity of the BZLF1 gene [7, 8]. These findings suggest that periodontitis is risk factor for EBV reactivation in infected individuals. 
Results of this study provides credence for potential interactions between EBV and P. gingivalis in the etiopathogenesis of periodontitis. EBV and periodontopathic bacteria co-existence apparently leads to additive effects and exacerbates the progress of periodontitis [33]. EBV-infected periodontium tends to harbor high levels of periodontopathic bacteria. Viral and bacterial co-existences were reported more frequently in deeper PD sites of CP patients [29, 30]. We have previously reported that coexistence of EBV DNA and $P$. gingivalis was significantly higher in CP patients with deeper PD sites (>5 mm; $40 \%$ ) than in those with shallow PD sites (<3 mm; 14\%) or healthy controls (13\%) [18]. In addition, coexistence of EBV DNA and $P$. gingivalis was significantly higher in the deeper PD sites $(>5 \mathrm{~mm}$ ) of CP patients $(68 \%)$ than in the PD sites of the healthy controls $(15 \%)$ and shallow PD sites (<3 mm) of CP patients (12\%) [19]. The data suggest that coexistence of EBV and $P$. gingivalis might increase the risk for developing periodontitis.

IPT was effective in reducing the coexistence of EBV and P. gingivalis in the subgingival plaque. Further studies are necessary to develop the new IPT procedure for keeping latency of EBV or reducing the coexistence of EBV and $P$. gingivalis.

\section{Conclusions}

IPT was effective in improvement of inflammatory conditions of periodontitis and reducing the coexistence of EBV and $P$. gingivalis in the subgingival plaque. However, IPT could not eradicate the EBV and P. gingivalis. Further research would be necessary for improving the periodontal treatment strategy.

\section{Abbreviations}

BOP: Bleeding on probing; CP: Chronic periodontitis; EBV: Epstein-Barr virus; GAPDH: Glyceraldehyde-3-phosphate dehydrogenase; HDAC: Histone deacetylase; IPT: Initial periodontal therapy; PCR: Polymerase chain reaction; PD: Probing pocket depth.

\section{Declarations}

\section{Acknowledgements}

Acknowledgement for cooperation in statistical analysis to Prof. Satoshi Horihata.

\section{Funding}

The study was supported in part by the Japan Society for the Promotion of Science KAKENHI Grants, Grant-in-Aid for Young Scientists (B); No.17K17361 and Scientific Research (C); No. 17K11994, No.19K10078 from the Ministry of Education, Science, Sports and Culture of Japan, and Nihon University Multidisciplinary Research Grant (17-019) for 2017-2018. The funding agencies were not involved in the design of the study; collection, analysis, and interpretation of data; or in writing the manuscript.

\section{Availability of data and materials}

The datasets used and/or analyzed during the current study available from the corresponding author on reasonable request.

\section{Authors' contributions}

$\mathrm{AK}, \mathrm{KI}$ and $\mathrm{YO}$ were responsible for design and conception of the study. AK, $\mathrm{YI}$ and $\mathrm{YO}$ performed follow-up care of patients and sample collection. All authors were involved in the analysis and interpretation of data. AK and YO was responsible for drafting the manuscript. All authors revised it critically and approved the final manuscript.

\section{Ethics approval and consent to participate}

The study had been approved by the Institutional Review Board at the Nihon University School of Dentistry at Matsudo (EC17-16-15-005-2), in accordance with the Declaration of Helsinki. Verbal and written informed consent was received from each subject were then clinically examined.

\section{Consent for publication}

Not applicable.

\section{Competing interests}

The authors declare that they have no competing interests.

\section{Author details}


${ }^{1}$ Department of Periodontology and Research Institute of Oral Science, Nihon University School of Dentistry at Matsudo, Chiba, 271-8587, Japan.

${ }^{2}$ Department of Microbiology, Division of Immunology and Pathobiology, Dental Research Center, Nihon University School of Dentistry, Tokyo, 102-8310, Japan.

\section{References}

1. Morita M, Wang HL. Effect of initial periodontal therapy on sulcular/tongue sulfide level. A pilot study. J Clin Periodontol. 2002 29:844-7.

2. Amoo-Achampong F, Vitunac DE, Deeley K, Modesto A, Vieira AR. Complex patterns of response to oral hygiene instructions: longitudinal evaluation of periodontal patients. BMC Oral Health. 2018, 18:72.

3. Tao Q, Young LS, Woodman CB, Murray PG. Epstein-Barr virus (EBV) and its associated human cancers--genetics, epigenetics, pathobiology and novel therapeutics. Front Biosci. 2006;11:2672-13.

4. Lin JC, Lin SC, De BK, Chan WP, Evatt BL. Precision of genotyping of Epstein-Barr virus by polymerase chain reaction using three gene loci (EBNA-2, EBNA-3C, and EBER): predominance of type A virus associated with Hodgkin's disease. Blood. 1993;81:3372-81.

5. Maeda E, Akahane M, Kiryu S, et al. Spectrum of Epstein-Barr virus-related diseases: a pictorial review. Jpn J Radiol. 2009;27:4-19.

6. Thorley-Lawson DA, Gross A. Persistence of the Epstein-Barr virus and the origins of associated lymphomas. N Engl J Med. 2004;350:1328-37.

7. Imai K, Inoue H, Tamura M, et al. The periodontal pathogen Porphyromonas gingivalis induces the Epstein-Barr virus lytic switch transactivator ZEBRA by histone modification. Biochimie. 2012;94: 839-46.

8. Imai K, Kamio N, Cueno ME, et al. Role of the histone H3 lysine 9 methyltransferase Suv39 h1 in maintaining Epsteinn-Barr virus latency in B95-8 cells. FEBS J. 2014;281:2148-58.

9. Timms JM, Bell A, Flavell JR, et al. Target cells of Epstein-Barr-virus (EBV)-positive post-transplant lymphoproliferative disease: similarities to EBV-positive Hodgkin's lymphoma. Lancet. 2003;361:217-23.

10. Toussirot E, Roudier J. Epstein-Barr virus in autoimmune diseases. Best Pract Res Clin Rheumatol. 2008;22:883-96.

11. Lai KY, Chou YC, Lin JH, et al. Maintenance of Epstein-Barr virus latent status by a novel mechanism, latent membrane protein 1induced interleukin-32, via the protein kinase C6 pathway. J Virol. 2015;89:5968-80.

12. D'Addario M, Libermann TA, Xu J, Ahmad A, Menezes J. Epstein-Barr virus and its glycoprotein-350 upregulate IL-6 in human Blymphocytes via CD21, involving activation of NF-kappaB and different signaling pathways. J Mol Biol. 2001;308:501-14.

13. Slots J, Saygun I, Sabeti M, Kubar A. Epstein-Barr virus in oral diseases. J Periodontal Res. 2006;41:235-44.

14. Corstjens PL, Abrams WR, Malamud D. Saliva and viral infections. Periodontol 2000. 2016;70:93-110.

15. Ikuta K, Satoh Y, Hoshikawa Y, Sairenji T. Detection of Epstein-Barr virus in salivas and throat washings in healthy adults and children. Microbes Infect. 2000;2:115-20.

16. Kamma JJ, Contreras A, Slots J. Herpes viruses and periodontopathic bacteria in early-onset periodontitis. J Clin Periodontol. $2001 ; 28: 879-85$.

17. Slots J, Kamma JJ, Sugar C. The herpesvirus-Porphyromonas gingivalis -periodontitis axis. J Periodontal Res. 2003;38:318-23.

18. Kato A, Imai K, Ochiai K, Ogata Y. Higher prevalence of Epstein-Barr virus DNA in deeper periodontal pockets of chronic periodontitis in Japanese patients. PLoS One. 2013;8(8): e71990.

19. Kato A, Imai K, Ochiai K, Ogata Y. Prevalence and quantitative analysis of Epstein-Barr virus DNA and Porphyromonas gingivalis associated with Japanese periodontitis patients. Clin Oral Investig. 2015;19:1605-10.

20. Zhu C, Li F, Wong MC, Feng XP, Lu HX, Xu W. Association between Herpesviruses and Chronic Periodontitis: A Meta-Analysis Based on Case-Control Studies. PLoS One. 2015;10:e0144319.

21. Lu H, Zhu C, Li F, Xu W, Tao D, Feng X. Putative periodontopathic bacteria and herpesviruses in pregnant women: a case-control study. Sci Rep. 2016;6:27796. 
22. Ogata Y, Nakayama Y, Tatsumi J, et al. Prevalence and risk factors for peri-implant diseases in Japanese adult dental patients. J Oral Sci. 2017;59:1-11.

23. Nakayama Y, Ogata Y, Hiromatsu Y, Imamura K, Suzuki E, Saito A, Shirakawa S, Nagano T, Gomi K, Morozumi T, Watanabe K, Akiishi K, Yoshie H. Clinical usefulness of novel immunochromatographic detection device for Porphyromonas gingivalis in evaluating effects of scaling and root planing and local antimicrobial therapy. J Periodontol. 2016;87:1238-47.

24. Kato A, Imai K, Sato H, Ogata Y. Prevalence of Epstein-Barr virus DNA and Porphyromonas gingivalis in Japanese peri-implantitis patients. BMC Oral Health. 2017;17:148.

25. Takada K, Horinouchi K, Ono Y, et al. An Epstein-Barr virus-producer line Akata: establishment of the cell line and analysis of viral DNA. Virus Genes. 1991;5:147-56.

26. Watanabe T, Maruyama F, Nozawa T, et al. Complete genome sequence of the bacterium Porphyromonas gingivalis TDC60, which causes periodontal disease. J Bacteriol. 2011;193:4259-60.

27. Slots J. Human viruses in periodontitis. Periodontol 2000. 2010; 53;89-110.

28. Socransky SS, Haffajee AD, Goodson JM, Lindhe J. New concepts of destructive periodontal disease. J Clin Periodontol. 1984;11:2132.

29. Chalabi M, Rezaie F, Moghim S, Mogharehabed A, Rezaei M, Mehraban B. Periodontopathic bacteria and herpesviruses in chronic periodontitis. Mol Oral Micobiol. 2010;25:236-40.

30. Özcan E, Saygun NI, Serdar MA, Kubar A, Bengi VU. Porphyromonas gingivalis and Epstein-Barr Virus are associated with increased levels of visfatin in gingival crevicular fluid. J Periodontol. 2016;87:443-51.

31. Saygun I, Kubar A, Ozdemir A, Yapar M, Slots J. Herpesviral-bacterial interrelationships in aggressive periodontitis. J Periodontal Res. 2004;39:207-212

32. Saygun I, Kubar A, Sahin S, Sener K, Slots J. Quantitative analysis of association between herpesviruses and bacterial pathogens in periodontitis. J Periodont Res. 2008;43:352-359.

33. Slots J. Herpesviral-bacterial interactions in periodontal diseases. Periodontol 2000. 2010;52:117-40.

\section{Tables}

Table 1 Characteristics of participants

\begin{tabular}{|c|c|c|}
\hline \multicolumn{3}{|c|}{ CP patients $(\mathrm{n}=17)$} \\
\hline & First visit & After IPT \\
\hline Age (years) & $44.8 \pm 14.9$ & \\
\hline Males & 7 (41.2\%) & \\
\hline Females & 10 (58.8\%) & \\
\hline \multirow[t]{2}{*}{$\mathrm{PD}(\mathrm{mm})$} & $2.94 \pm 0.24(\mathrm{HS})$ & $2.82 \pm 0.39(\mathrm{HS})$ \\
\hline & $7.35 \pm 1.54(\mathrm{PS})$ & $5.76 \pm 1.68(\mathrm{PS})^{* *}$ \\
\hline \multirow[t]{2}{*}{ CAL (mm) } & $3.65 \pm 1.37(\mathrm{HS})$ & $3.82 \pm 1.51(\mathrm{HS})$ \\
\hline & $8.76 \pm 1.92(\mathrm{PS})$ & $7.47 \pm 1.74(\mathrm{PS})$ \\
\hline \multirow[t]{2}{*}{ BOP } & $2(11.8 \%)(\mathrm{HS})$ & $0(0 \%)$ \\
\hline & 17 (100\%) (PS) & $11(65 \%)^{* *}$ \\
\hline
\end{tabular}

Chronic periodontitis (CP), initial periodontal therapy (IPT),

probing pocket depth (PD), bleeding on probing (BOP),

clinical attachment level (CAL), healthy sites (HS), periodontitis sites (PS)

Statistically significant; $P<0.01^{* *}$ 
Table 2 Clinical data and counts of EBV DNA and $P$. gingivalis in the HS at first visit and after IPT

First visit $\quad$ After IPT

\begin{tabular}{|c|c|c|c|c|c|c|c|c|c|c|c|c|}
\hline $\begin{array}{c}\text { Subject } \\
\text { No. } \\
\end{array}$ & Gender & Age & $\begin{array}{c}(\leqq 3) \\
\text { PD (mm) }\end{array}$ & CAL (mm) & BOP & $\begin{array}{c}\text { (Copies/ml) } \\
\text { EBV } \\
\end{array}$ & $\begin{array}{l}\text { (Copies } / \mathrm{ml}) \\
\text { P. gingivalis }\end{array}$ & $\begin{array}{c}(\leqq 3) \\
\mathrm{PD}(\mathrm{mm})\end{array}$ & & BOP & $\begin{array}{c}\text { (Copies/ml) } \\
\text { EBV } \\
\end{array}$ & $\begin{array}{l}\text { (Copies/ml) } \\
\text { P. gingivalis }\end{array}$ \\
\hline 1 & Female & 27 & 3 & 3 & a & ND & $9.21 \times 10^{3}$ & 3 & 3 & प & ND & $6.35 \times 10^{3}$ \\
\hline 2 & Female & 39 & 3 & 8 & + & $4.49 \times 10^{3}$ & $4.71 \times 10^{8}$ & 3 & 9 & a & ND & $7.61 \times 10^{7}$ \\
\hline 3 & Female & 28 & 2 & 2 & a & ND & $5.71 \times 10^{7}$ & 3 & 3 & a & ND & ND \\
\hline 4 & Male & 38 & 3 & 3 & a & ND & ND & 2 & 5 & a & ND & ND \\
\hline $\mathbf{5}$ & Female & 41 & 3 & 3 & 0 & $4.48 \times 10^{3}$ & $1.11 \times 10^{4}$ & 3 & 3 & प & ND & $8.24 \times 10^{3}$ \\
\hline 6 & Female & 70 & 3 & 3 & प & $3.40 \times 10^{3}$ & $2.40 \times 10^{3}$ & 3 & 3 & प & ND & ND \\
\hline 7 & Female & 31 & 3 & 4 & a & ND & $1.34 \times 10^{3}$ & 3 & 4 & 0 & $1.03 \times 10^{3}$ & $1.45 \times 10^{2}$ \\
\hline 8 & Female & 42 & 3 & 3 & a & ND & $8.24 \times 10^{3}$ & 3 & 3 & a & ND & $2.75 \times 10^{3}$ \\
\hline 9 & Male & 72 & 3 & 5 & 0 & $3.18 \times 10^{3}$ & $4.30 \times 10^{4}$ & 2 & 3 & 0 & ND & $6.29 \times 10^{4}$ \\
\hline 10 & Female & 59 & 3 & 5 & प & $1.09 \times 10^{4}$ & $3.61 \times 10^{6}$ & 2 & 4 & प & ND & $9.50 \times 10^{3}$ \\
\hline 11 & Male & 47 & 3 & 3 & a & $8.34 \times 10^{3}$ & $8.14 \times 10^{5}$ & 3 & 4 & a & $7.94 \times 10^{3}$ & $3.70 \times 10^{4}$ \\
\hline 12 & Male & 73 & 3 & 3 & a & ND & $5.29 \times 10^{1}$ & 3 & 3 & a & ND & 4.34 \\
\hline 13 & Female & 46 & 3 & 4 & a & $2.52 \times 10^{2}$ & $8.59 \times 10^{2}$ & 3 & 3 & प & $6.12 \times 10^{2}$ & $1.65 \times 10^{3}$ \\
\hline 14 & Male & 24 & 3 & 3 & प & ND & ND & 3 & 3 & 口 & ND & ND \\
\hline 15 & Male & 43 & 3 & 3 & प & $3.75 \times 10^{3}$ & ND & 3 & 3 & a & $2.10 \times 10^{3}$ & $1.23 \times 10^{3}$ \\
\hline 16 & Male & 37 & 3 & 3 & व & $4.56 \times 10^{3}$ & $3.81 \times 10^{3}$ & 3 & 4 & a & $8.41 \times 10^{3}$ & $4.13 \times 10^{1}$ \\
\hline 17 & Female & 44 & 3 & 4 & + & ND & $3.39 \times 10^{5}$ & 3 & 5 & a & ND & $1.27 \times 10^{3}$ \\
\hline
\end{tabular}

not detectable (ND), initial periodontal therapy (IPT), Clinical attachment level (CAL)

Table 3 Clinical data and counts of EBV DNA and P. gingivalis in the PS at first visit and after IPT

First visit $\quad$ After IPT

\begin{tabular}{|c|c|c|c|c|c|c|c|c|c|c|c|c|}
\hline $\begin{array}{c}\text { Subject } \\
\text { No. }\end{array}$ & Gender & Age & $\begin{array}{c}(\geqq 5) \\
\mathrm{PD}(\mathrm{mm})\end{array}$ & $\mathrm{CAL}(\mathrm{mm})$ & BOP & $\begin{array}{c}\text { (Copies/ml) } \\
\text { EBV }\end{array}$ & $\begin{array}{l}\text { (Copies/ml) } \\
\text { P. gingivalis }\end{array}$ & $\begin{array}{c}(\geqq 5) \\
\mathrm{PD}(\mathrm{mm})\end{array}$ & CAL (mm) & BOP & $\begin{array}{c}\text { (Copies/ml) } \\
\text { EBV }\end{array}$ & $\begin{array}{l}\text { (Copies/ml) } \\
\text { P. gingivalis }\end{array}$ \\
\hline 1 & Female & 27 & 6 & 7 & + & $2.98 \times 10^{3}$ & $8.41 \times 10^{8}$ & 6 & 7 & प & ND & $1.91 \times 10^{8}$ \\
\hline 2 & Female & 39 & 8 & 12 & + & $2.38 \times 10^{3}$ & $3.56 \times 10^{8}$ & 6 & 11 & + & $1.47 \times 10^{3}$ & $2.70 \times 10^{9}$ \\
\hline 3 & Female & 28 & 8 & 9 & + & $8.36 \times 10^{3}$ & $3.69 \times 10^{8}$ & 6 & 7 & + & $8.59 \times 10^{3}$ & ND \\
\hline 4 & Male & 38 & 6 & 7 & + & ND & ND & 5 & 6 & + & ND & ND \\
\hline 5 & Female & 41 & 8 & 10 & + & ND & $2.84 \times 10^{9}$ & 8 & 9 & + & $1.78 \times 10^{3}$ & $2.87 \times 10^{8}$ \\
\hline 6 & Female & 70 & 10 & 10 & + & ND & $2.28 \times 10^{3}$ & 9 & 10 & + & ND & ND \\
\hline 8 & Female & 42 & 6 & 7 & + & $8.36 \times 10^{3}$ & $1.89 \times 10^{5}$ & 6 & 6 & प & $6.29 \times 10^{3}$ & $1.53 \times 10^{3}$ \\
\hline 9 & Male & 72 & 8 & 11 & + & $5.65 \times 10^{3}$ & $6.21 \times 10^{9}$ & 6 & 8 & प & $6.50 \times 10^{2}$ & $8.23 \times 10^{5}$ \\
\hline 10 & Female & 59 & 7 & 9 & + & $2.55 \times 10^{4}$ & $4.43 \times 10^{9}$ & 3 & 5 & प & $5.72 \times 10^{3}$ & $7.66 \times 10^{6}$ \\
\hline 11 & Male & 47 & 6 & 7 & + & $3.78 \times 10^{1}$ & $1.42 \times 10^{6}$ & 6 & 7 & + & ND & $1.05 \times 10^{9}$ \\
\hline 12 & Male & 73 & 8 & 10 & + & $5.88 \times 10^{3}$ & $4.13 \times 10^{6}$ & 3 & 7 & + & $1.15 \times 10^{3}$ & ND \\
\hline 13 & Female & 46 & 6 & 6 & + & $1.57 \times 10^{2}$ & $2.14 \times 10^{8}$ & 3 & 5 & ] & $5.29 \times 10^{3}$ & ND \\
\hline 14 & Male & 24 & 10 & 11 & + & $2.37 \times 10^{2}$ & $2.75 \times 10^{7}$ & 6 & 8 & + & ND & ND \\
\hline 15 & Male & 43 & 6 & 6 & + & ND & ND & 6 & 6 & + & ND & ND \\
\hline 16 & Male & 37 & 6 & 8 & + & $8.89 \times 10^{3}$ & ND & 6 & 8 & 0 & ND & $9.97 \times 10^{1}$ \\
\hline
\end{tabular}

not detectable (ND), initial periodontal therapy (IPT), Clinical attachment level (CAL)

Table 4 Occurrence of EBV DNA and $P$. gingivalis in the subgingival samples from HS at

first visit and after IPT

Detection frequency Significance $(P$-value $)$

Infectious agents First visit After IPT First visit vs After IPT

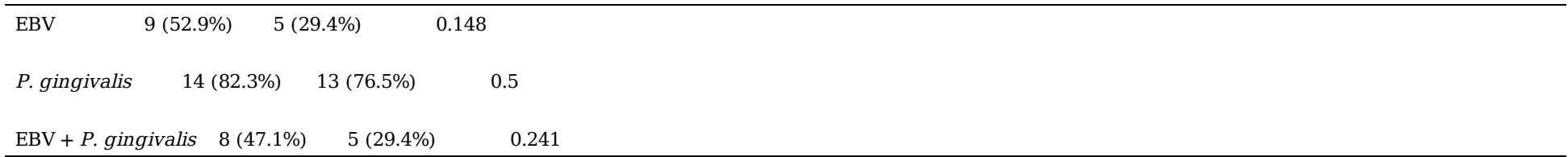


Healthy sites (HS), initial periodontal therapy (IPT)

Table 5 Occurrence of EBV DNA and P. gingivalis in the subgingival samples from PS at

first visit and after IPT

Detection frequency $\quad$ Significance $(P$-value $)$

Infectious agents First visit After IPT First visit vs After IPT

EBV $\quad 13(76.5 \%) \quad 9(52.9 \%) \quad 0.141$

P. gingivalis $14(82.3 \%) \quad 10(58.8 \%) \quad 0.129$

EBV $+P$. gingivalis $12(70.6 \%) \quad 6(35.3 \%) \quad 0.042 *$

Periodontitis sites (PS), initial periodontal therapy (IPT), Statistically significant; $P<0.05^{*}$ 